\title{
Evaluation of Trace Elements in Prochilodus lineatus (Valenciennes, 1837) (Characiformes, Prochilodontidae) from the Mogi Guaçu River Infected for Acanthocephala Neoechynorhyncus Curemai Noronha, 1973 (Acanthocephala)
}

Cintia Moreira Ramos dos Reis ${ }^{{ }^{*}}$, Naira da Siva Campos ${ }^{2}$, Marlene Tiduko Ueta ${ }^{1}$, Júlio César José da Silva ${ }^{2}$, Paulo Sérgio Ceccarelli ${ }^{3}$ and Silmara Marques Allegrette ${ }^{1}$

${ }^{1}$ Department of Animal Biology, State University of Campinas, Monteiro Lobato 255, Campinas, São Paulo, Brazil

${ }^{2}$ Department of Analytical Chemistry, Federal University of Juiz de Fora, Rua José Lourenço Kelmer, Juiz de Fora, Minas Gerais, Brazil

${ }^{3}$ Chico Mendes Institute for Biodiversity Conservation, Pirassununga, São Paulo, Brazil

\begin{abstract}
The basin of the Rio Mogi Guaçu has one of the best fish faunas studied in Brazil. Their fish are an important source of food for the inhabitants of the region, but due to human impact suffering along its course, it is relevant to do an analysis of contamination by trace elements. The objectives of this study were to analyze the presence of trace elements, copper, chromium, lead and zinc, and compare the trace element concentration in muscles and fish liver and intestinal parasites. 229 specimens were collected in 2012 of Prochilodus lineatus, known as curimbatá, in Cachoeira de Emas, Pirassununga. Muscle and liver samples were collected and analyzed to obtain the concentration of trace elements as well as intestinal parasites to evaluate the investigated analytes. Atomic absorption spectrometry in flame mode (F AAS) and graphite furnace mode (GF AAS) was employed to quantify the analytes. Digestion samples were analyzed using method EPA-3050B (modified). The concentration of trace elements in parasites Neoechinorhynchus curemai was higher than in the fish tissues indicating that these organisms can be good indicators of the presence of trace elements and pollution.
\end{abstract}

Keywords: Acanthocephala; Prochilodus lineatus; Mogi Guaçu River; Trace elements

\section{Introduction}

The Mogi Guaçu River is born on the hill of Curvado, municipality of Bom Repouso, in the Serra da Mantiqueira region, state of Minas Gerais, Brazil. In the region of the municipality of Pirassununga (SP), among the various environmental impacts, we highlight the anthropic sources of pollution, such as the cultivation of sugar cane. Also, the installation of industries and the commerce of brandy, with the dumping of pesticides, fertilizers and soil correctives in the river, which can carry substances such as copper, mercury, lead and zinc, as well as industrial sewage $[1,2]$. These factors turn the river a potential reservoir of nonorganic elements, such as trace elements, that can concentrate on the riverbed or be ingested by fish and other animals, including man. This last issue is especially important considering that one of the main species of fish traded in the country is found in the Mogi Guaçu river, the curimbatá, Prochilodus lineatus [3].

The aspects inherent to the pollution and accumulation of trace elements that the Mogi Guaçu river has been suffering for 100 years have never been associated with the ichthyoparasitary dynamics [1]. This type of approach is very common in countries such as Germany and Austria, where Scheef et al. [4,5] concluded that fish parasites are excellent environmental bioindicators due to their ability to accumulate larger amounts of trace elements. A proposal in this sense is necessary in order to understand the dynamics of the parasitofauna and to evaluate the quality of the aquatic ecosystem through the intestinal parasites.

A study of current levels of some trace elements was done to ascertain the environmental history of the Mogi Guaçu River, through the technique of sediment profile dating through the ${ }^{219} \mathrm{~Pb}$ methodology, in three bottom sediment profiles at the Rio das Pedras lagoon in Pirassununga. The results of deposition rates observed between 0.6 and $0.1 \mathrm{~cm}$ year ${ }^{-1}$ showed that the $25 \mathrm{~cm}$ depth profile corresponds to 135 years of history of deposition of suspended material in the lagoon [1].
The most used parasites for this evaluation have been the intestinal parasites, acanthocephala and cestode. The concentration of accumulated toxins in their tissues provides information about the environment in which they are found and analyses show a relationship between parasite weight and trace element concentration. Mortality by high concentrations of trace elements has not been observed in the parasites [6-8].

Thus, the study proposed here addresses the increase in knowledge of the increase in trace element concentration, and the effect on the parasite species and on the tissues of the fish studied. The proposal of the present study proved to be relevant because the Mogi-Guaçu river is very impacted due to the accelerated growth of the cities in recent years and that has led to considerable environmental degradation [9].

\section{Materials and Methods}

The study was carried out in the Mogi-Guaçu River, in the district of Cachoeira de Emas, municipality of Pirassununga (SP) Brazil. The site of analysis of the specimens collected was the Health, Welfare and Disease Control laboratory of CEPTA/ICMBio (National Center for Research and Conservation of Continental Fishes and Chico Mendes Institute for Biodiversity Conservation).

*Corresponding author: Cintia Moreira Ramos dos Reis, Department of Animal Biology, State University of Campinas, Monteiro Lobato 255, Campinas, São Paulo, Brazil, Tel: 5532999217275; E-mail: cinmoreira@gmail.com

Received April 12, 2017; Accepted April 19 , 2017; Published April 24, 2017

Citation: dos Reis CMR, da Siva Campos N, Ueta MT, da Silva JCJ, Ceccarelli PS, et al. (2017) Evaluation of Trace Elements in Prochilodus lineatus (Valenciennes, 1837) (Characiformes, Prochilodontidae) from the Mogi Guaçu River Infected for Acanthocephala Neoechynorhyncus Curemai Noronha, 1973 (Acanthocephala). J Environ Anal Toxicol 7: 458. doi: 10.4172/2161-0525.1000458

Copyright: @ 2017 dos Reis CMR, et al. This is an open-access article distributed under the terms of the Creative Commons Attribution License, which permits unrestricted use, distribution, and reproduction in any medium, provided the original author and source are credited. 
Citation: dos Reis CMR, da Siva Campos N, Ueta MT, da Silva JCJ, Ceccarelli PS, et al. (2017) Evaluation of Trace Elements in Prochilodus lineatus (Valenciennes, 1837) (Characiformes, Prochilodontidae) from the Mogi Guaçu River Infected for Acanthocephala Neoechynorhyncus Curemai Noronha, 1973 (Acanthocephala). J Environ Anal Toxicol 7: 458. doi: 10.4172/2161-0525.1000458

Page 2 of 4

The work was approved by the Animal Use Ethics Committee of the State University of Campinas (CEUA/UNICAMP), protocol number 2645-1, and was in accordance with the ethical principles in animal experimentation adopted by the Brazilian Society of Sciences in Laboratory Animals (SBCAL) and with the current legislation, Law no. 11.794, dated October 8, 2008 and decree no. 6.899, dated July 15, 2009, and the collections were approved by Sisbio, protocol number 37336-1.

Monthly collection expeditions were carried out between January and December 2012, covering the drought and flood periods of the river, near the dam of Cachoeira de Emas, Pirassununga, SP $\left(21^{\circ} 55\right.$ 'S and $47^{\circ} 22^{\prime} \mathrm{W}$ ). During the study, 229 specimens of Prochilodus lineatus were collected with the aid of nets and flasks, each specimen being weighed and measured (standard measure).

Liver and muscle tissue samples were removed between the fins of the dorsal region, conditioned and then frozen at a temperature of $-1^{\circ} \mathrm{C}$. The acanthocephalan parasites were removed using tweezers and stylet and placed in $2.5 \mathrm{ml}$ Eppendorf plastic tubes with distilled water and frozen. The analysis of trace elements in fish was carried out in the Baccan Laboratory of Analytical Chemistry, Department of Chemistry, University Federal of Juiz de Fora, by means of an flame atomic absorption spectrophotometer (F AAS). The method of opening the tissue samples was adapted from the official EPA (Environmental Protection Agency) method 3050B for the digestion of sediment samples (EPA, 1996). The analysis of the acanthocephalan parasites was performed in a graphite furnace atomic absorption spectrophotometer (GF AAS) and the opening method was through concentrated nitric acid heated at low temperature for up to two hours in hot plate.

All glassware and objects used for analysis were decontaminated in an acid bath $\left(10 \% \mathrm{v} / \mathrm{v} \mathrm{HNO}_{3}\right)$ for 24 hours and washed with deionized water prior to use. All solutions were prepared with purified water at 18 $\mathrm{M} \Omega$ in Milli- $\mathrm{Q}^{\circ}$ system (Millipore). The determination of trace elements was done by double atomization equipment (flame and graphite furnace), Thermo Scientific model, Solaar M5 series, with automatic sampler in oven mode (Thermo Scientific, model GF 95) and equipped with a deuterium background correction system. The gaseous mixture used for the analyzes was $\mathrm{Ar} / \mathrm{C}_{2} \mathrm{H}_{2}$ flowing at $4 \mathrm{~L} / \mathrm{min}$. All measurements were performed at wavelength, $357.8 \mathrm{~nm}$ for chromium $(\mathrm{Cr}), 324.8$ $\mathrm{nm}$ for copper $(\mathrm{Cu}), 217 \mathrm{~nm}$ for lead $(\mathrm{Pb})$ and $213.8 \mathrm{~nm}$ for zinc $(\mathrm{Zn})$, respectively.

Samples were prepared by dehydrating the tissues at $75^{\circ} \mathrm{C}$ for 24 hours in a greenhouse, these samples were separated by month, and then crushed with the aid of a mixer (Philips Walita Viva Collection RI1366 Mixer) for homogenization of the same. Using an analytical balance (AND HR 120), an aliquot of $0.5 \mathrm{~g}$ was removed and digestion was started in acidic medium.

The steps of the acid digestion method follow the following order: after preparation of the sample $10 \mathrm{ml}(1: 1) \mathrm{HNO}_{3}$ and deionized $\mathrm{H}_{2} \mathrm{O}$ were added to the samples that were in $50 \mathrm{ml}$ glass beakers, taken to the hot plate, kept until the reduction of volume to approximately 1 $\mathrm{mL}$, then $5 \mathrm{~mL}$ of concentrated $\mathrm{HNO}_{3}$ was added, and again brought to the warming to reduce the volume, $2 \mathrm{~mL}$ of $\mathrm{H}_{2} \mathrm{O}$ and $3 \mathrm{~mL}$ of $\mathrm{H}_{2} \mathrm{O}_{2}$ were added to the sample and heated, $1 \mathrm{~mL}$ of $\mathrm{H}_{2} \mathrm{O}_{2}, 5 \mathrm{~mL}$ of $\mathrm{HCl}$ were placed in the sample and heated. After this step the sample was placed in a Falcon tube and the volume filled with deionized water. For the digestion of fish samples, the adaptations were made, only the first two steps were necessary to fully open the samples [10].

The samples were placed in $50 \mathrm{~mL}$ Falcon tapered tubes and the volume filled with deionized $\mathrm{H}_{2} \mathrm{O}$. All steps were performed under heating at $60^{\circ} \mathrm{C}$ in a hot plate until the volume was almost reduced to dryness. Samples were taken in triplicates, when possible. The standard solutions used for the construction of the analytical curves were prepared from the stock solutions of $\mathrm{Cr}, \mathrm{Pb}, \mathrm{Cu}$ and $\mathrm{Zn}$ with concentration of $1000 \mathrm{mgL}^{-1}$. Analytical standards and blanks solutions were prepared in acid medium $\left(0.1 \% \mathrm{v} / \mathrm{v} \mathrm{HNO}_{3}\right)$. In order to obtain the concentration of the analytes in the samples, a multi-calibration curve was made for $\mathrm{Cr}, \mathrm{Pb}$ and $\mathrm{Cu}$ ranging from 0.1 to $3.0 \mathrm{mgL}^{-1}$ and for $\mathrm{Zn}$ the curve showed concentrations between 0.1 to $2.0 \mathrm{mgL}^{-1}$. Then the analytes were determined F AAS. All readings were made in triplicates and the analyte concentrations were expressed in milligrams per $100 \mathrm{~g}$ of sample [11].

The parasites Neoechynorhynchus curemai (Acanthocephala) from curimbatá were separated by season and packed in Eppendorf-type tubes and frozen for trace element analysis, tissue samples were also separated by conditioned and frozen season. The trace elements studied in the muscle and liver samples were $\mathrm{Cr}, \mathrm{Cu}, \mathrm{Pb}, \mathrm{Zn}$, which present a maximum tolerance limit allowed by the Ministry of Health through decree 55.871 of March 26, 1965 and by Mercosur Ordinance No. 685, of 27 August 1998. For GF AAS measurements the parasites were dehydrated in greenhouses for two hours, then crushed and weighed and digestion was started through $500 \mu \mathrm{L}$ of concentrated nitric acid in a hot plate at $60^{\circ} \mathrm{C}$, then the volume was filled to $1 \mathrm{~mL}$ with deionized water. The calibration curve followed concentrations $2.5 \mu \mathrm{L} ; 5.0 \mu \mathrm{L} ; 10 \mu \mathrm{L} ; 20$ $\mu \mathrm{L} ; 30 \mu \mathrm{L}$ and $40 \mu \mathrm{L}$ for the analytes. The standard preparation was done with the stock concentration of $1000 \mathrm{mgL}^{-1}$; from this it was done the dilution to $2 \mathrm{mgL}^{-1}$ in a volume of $20 \mu \mathrm{L}$ in a $10 \mathrm{~mL}$. This concentration was again diluted in a $10 \mathrm{~mL}$ flask to obtain a volume of $500 \mu \mathrm{L}$ of each standard, then $100 \mu \mathrm{L}$ of nitric acid was added and the volume was filled with deionized water [12].

The value of the bioaccumulation of trace elements present in the tissues of the parasites and their hosts was calculated from the method suggested by Sures et al. [13], using the formula: C [parasite]/C [host organ].

\section{Results}

Table 1 shows the maximum values of trace elements allowed by the Ministry of Health of Brazil (through decree 55.871 of March 26, 1965 ) and those obtained in this work. Zinc presented values below the limit allowed by the Ministry of Health in all seasons of the year. Chromium was found in high quantity in all seasons of the year. Lead was found above the maximum tolerance value only in the liver in the rainy season, in the other stations and tissues the values were below the limit of detection (LD). Copper presented high values in the liver in both seasons of the year, and in the muscle these values are below the maximum allowed.

\section{Discussion}

Zinc acts on the growth, development and differentiation of organisms, and can also act as an enzymatic cofactor, known as metalloenzyme, and is most often associated with proteins [14]. For the present study, zinc was found in both muscle and liver in concentrations lower than the maximum tolerance limit for the species, and it was not toxic, but in case of increased concentration, this would lead to fish problems related to growth and maturation. In Acanthocephala the zinc concentration was low. According to a study by Sures et al. [15], the concentration of zinc found in the parasite Acanthocephalus lucii was higher than that observed in the tissues of Perca fluviatilis L. 1758, a different result of the present work that did not find zinc at concentrations detectable by the equipment. 
Citation: dos Reis CMR, da Siva Campos N, Ueta MT, da Silva JCJ, Ceccarelli PS, et al. (2017) Evaluation of Trace Elements in Prochilodus lineatus (Valenciennes, 1837) (Characiformes, Prochilodontidae) from the Mogi Guaçu River Infected for Acanthocephala Neoechynorhyncus Curemai Noronha, 1973 (Acanthocephala). J Environ Anal Toxicol 7: 458. doi: 10.4172/2161-0525.1000458

Page 3 of 4

\begin{tabular}{|c|c|c|c|c|c|c|c|c|}
\hline & \multicolumn{2}{|c|}{$Z n$} & \multicolumn{2}{|c|}{$\mathrm{Cr}$} & \multicolumn{2}{|c|}{$\mathrm{Pb}$} & \multicolumn{2}{|c|}{$\mathrm{Cu}$} \\
\hline & Rain & Dry & Rain & Dry & Rain & Dry & Rain & Dry \\
\hline Muscle mgKg ${ }^{-1}$ & 2.2 & 4.1 & 4.2 & 9.1 & $<\mathrm{DL}$ & $<\mathrm{DL}$ & 3.5 & 11.1 \\
\hline Liver $\mathrm{mgKg}^{-1}$ & 36.4 & 35 & 109.1 & 72.4 & 42.8 & $<\mathrm{DL}$ & 324.1 & 660.5 \\
\hline $\begin{array}{l}\text { Neoechynorhynchus curemai } \\
\qquad \mathrm{mgKg}^{-1}\end{array}$ & $<\mathrm{DL}$ & $<\mathrm{DL}$ & 869.3 & $2.268,5$ & 749.6 & 828.5 & $52.286,9$ & $18.382,8$ \\
\hline MVA mgKg $^{-1}$ & \multicolumn{2}{|c|}{50.0} & \multicolumn{2}{|c|}{0.10} & \multicolumn{2}{|c|}{2.0} & \multicolumn{2}{|c|}{30.0} \\
\hline
\end{tabular}

MVA: Maximum values allowed according to Ministry of Health; DL: Detection limit; Bold values represent trace elements above the limit allowed by the Ministry of Health Table 1: Mean of $\mathrm{Zn}, \mathrm{Cr}, \mathrm{Pb}$ and $\mathrm{Cu}$ trace element concentration in Prochilodus lineatus and Intestinal Neoechynorhynchus curemai parasites in the two seasons of 2012 in the Mogi Guaçu River, Cachoeira de Emas.

Chromium acts on endocrine dysfunction in fish from polluted waters and analyzes have shown that a high concentration of $\mathrm{Cr}$ may lead to reduction of spleen and kidney size by altering the number and profile of immune cells in blood and tissues under study with Saccobranchus fossilis [14]. In the present work the concentration of chromium in P. lineatus was above the limit of tolerance in muscle and liver. The high concentration may affect the physiology of the specimens studied, but it was not possible to infer about these alterations. A concentration of chromium 80 times higher in the acanthocephalus was observed when compared to the liver in the rainy season, in the dry season this concentration is 31.3 times higher in the parasite. For the muscle this value in the dry is of 249.3 and in the period of rain is of 207 times greater in the tissues of the parasite. Galli et al. [16] studying the concentration of two trace elements $(\mathrm{Pb}$ and $\mathrm{Cr})$ in the liver of Leuciscus cephalus and the parasite A. anguillae, found a 60fold higher concentration of chromium in the parasite. These values show the high capacity of the Acanthocephala in the bioconcentration of trace elements in their tissues, showing to be an excellent biological indicator $[6,17,18]$.

Lead is a toxic trace element, which does not undergo biomagnification, as well as zinc, copper and chromium, although they may bioconcentrate. Lead, zinc and copper are known to inhibit the sulfotransferase enzyme in fish Danio rerio (Hamilton, 1822) at high concentrations [14]. The sulfhydryl group (-SH), commonly occurs in enzymes controlling the rate of metabolic reactions, lead has a strong affinity to sulfur, forming a bond (metal-sulfur) that affects the enzyme, preventing its normal action [19].

The high concentration of lead found in the liver is a factor that can interfere in the reproduction of fish [14], in the present work a concentration was found above the limit allowed, and could interfere in the reproduction of curimbatá. In an experiment with Rhamdia quelen for evaluation of the presence of lead and artificial fertilization showed that at the time of fertilization until the first eight hours of artificial incubation of the eggs, in a concentration higher than $0.25 \mathrm{mgL}^{-1}$, there was a deleterious effect on the percentage of fertilized eggs, showing that with increasing lead concentration fertilization decreased linearly [20].

The concentration of lead in the parasite Neoechynorhynchus curemai was 17.5 times higher than in the liver during the rainy season. This high concentration was also observed by Galli et al. [16], in the Lambro river with the fish Leuciscus cephalus and the intestinal parasite Acanthocephalus anguillae, finding 200 times more lead in the parasite compared to the liver of the fish. In the muscle, it was not possible to evaluate the bioaccumulation, since the lead values were below the detection limit of the equipment, the same occurring for the liver in the dry season.

Environmental factors influence the chemical form of copper (such as the $\mathrm{pH}$ of water that influences its toxicity), altering its bioavailability and effect on the body. The effects of $\mathrm{pH}$ on copper toxicity are of particular importance in soft and low alkalinity waters, such as most Brazilian inland waters. Copper also inhibits the absorption of ions, as well as, increase the loss of ions in the cells by diffusion, which can potentiate the effects of $\mathrm{pH}$. In acid environments, the most bioavailable form of copper is free cation $\left(\mathrm{Cu}^{+2}\right)$. In the Mogi Guaçu river the $\mathrm{pH}$ of the water is currently between 6.6 and 7 (CETESB, 2013), values slightly above that typical for the formation of copper hydroxide [14]

The accumulation of copper in the tissues of fish exposed to acid $\mathrm{pH}$ is higher than in fish exposed to neutral and alkaline $\mathrm{pH}$. Its chronic toxicity initially affects the liver because it is the first site of deposition after entering the bloodstream, which can lead to changes in blood parameters such as hematocrit and hemoglobin concentration. In fish there are reports that copper can both stimulate and inhibit antioxidant enzymes, depending on the dose, species and/or route of exposure. As a result, fish metabolism requires high energy to survive the effects of temperature, $\mathrm{pH}$ and copper [21]. Copper directly interferes with the gill permeability, increasing the $\mathrm{Na}^{+}, \mathrm{Cl}^{-}$and $\mathrm{K}^{+}$flux, in addition, exposure to copper can lead to suppression of specific antibody responses, in addition to increasing incidence of infections. In a study with Oncorhynchus mykiss, Di Giulio et al. observed that the percentage of circulating lymphocytes was 9 to $13 \%$ lower than control values, while monocytes were elevated in fish exposed to $27 \mu \mathrm{g} \mathrm{Cu} / \mathrm{L}$. There was also an increase in neutrophils in trout exposed to concentrations of $6 ; 16$ and $27 \mu \mathrm{g} \mathrm{Cu} / \mathrm{L}$ copper.

The present study draws attention to the concentration of copper in the liver of $P$. lineatus analyzed, with values considerably higher than that indicated by the Ministry of Health of Brazil as the maximum acceptable. It was observed a higher concentration of copper in the liver for both seasons of the year. For the muscle, the values in the drought were higher, during which the fish were found in the feeding homes, with the result that their energy expenditure was lower, for fat accumulation.

The other trace elements found in curimbatás were more present in the rainy season (spring-summer). A possible explanation for the higher concentration of copper in the dry season may be related to the level of water, since in the periods of high water temperatures, it is important to note that most of the trace elements only bioaccumulate in the tissues [19,22], a possible explanation for the higher concentration of copper in the dry season may be linked to the water level, because in periods of drought the river has a lower flow rate and with this a greater accumulation of trace elements occurs. It can also be inferred that this high value of copper concentration may be related to the feeding of the animals that in the dry season is higher due to the fact that the individuals are present at the place [3]. The fact that this species also has a permanent population close to the Cachoeira de Emas dam [23], may be one of the explanations for this high concentration of copper, which concentrate this element through food and gills [14].

Since high concentrations of three trace elements $(\mathrm{Pb}, \mathrm{Cr}$ and $\mathrm{Cu}$ ) have been found, it is not possible to say which one acts on the possible physiological changes in curimbatás, or if the three elements 
Citation: dos Reis CMR, da Siva Campos N, Ueta MT, da Silva JCJ, Ceccarelli PS, et al. (2017) Evaluation of Trace Elements in Prochilodus lineatus (Valenciennes, 1837) (Characiformes, Prochilodontidae) from the Mogi Guaçu River Infected for Acanthocephala Neoechynorhyncus Curemai Noronha, 1973 (Acanthocephala). J Environ Anal Toxicol 7: 458. doi: 10.4172/2161-0525.1000458

Page 4 of 4

act concomitantly and/or synergistically. However, it can be argued that this high level of trace elements in the tissues of $P$. lineatus is not appropriate, and the increase in these concentrations and the lack of monitoring may in the future cause serious problems, not only for this, but for the other species that are found in the Mogi Guaçu river.

Parasites may become allies of their hosts in certain situations as suggested by Fellous and Salvaudon [24]. Some parasites in specific environments may bring advantages to the host by producing substances that may be lacking in the environment, or by developing functions that favor their hosts to survive in adverse conditions. In the case of acanthocephalans, the absorption of large amounts of trace elements in their own tissues reduces the concentration found in the tissues of their hosts, allowing infected fish to tolerate more strongly polluted environments. The analysis of the acanthocephala showed that the concentration of copper in their tissues was about 28 times higher than in fish liver in the dry season and in the rainy season was approximately 160 times greater. In the muscle the ratio of parasite/ host concentration in the dry season was more than 1600 times higher for copper in the acanthocephala in the dry period and in the rain this ratio was around 15,000. Nachev et al. [17] found that in a study carried out on the Danube River, copper concentration 95 times higher in the parasite Pomphorhynchus laevis when compared to the Barbus barbus fish muscle, corroborating the behavior observed in the present study.

The high concentration of these trace elements in the intestinal parasites of $P$. lineatus demonstrates how impacted this environment is and that these organisms are good indicators of pollution and are indicated for trace elements concentration analyzes. The results also showed that the populations of curimbata in the Mogi Guaçu river undergo changes, be they biological, or environmental, by the pollution present in the place with great concentration of toxic elements, or even within the population. High concentrations of lead, chromium and copper were found in the tissues, mainly in fish liver, showing that the environment is polluted and the high concentration of these elements in the studied parasites confirm that they are an appropriate option to be used as models of environmental bioindicators.

\section{Acknowledgments}

The authors would like to thank the Coordination for the Improvement of Higher Education Personnel (CAPES) for the granting of a doctorate scholarship for research, to CEPTA, for logistical support. The authors would like to thank CNPq (Conselho Nacional de Desenvolvimento Científico e Tecnológico), FAPEMIG (Fundação de Amparo à Pesquisa do Estado de Minas Gerais), Rede Mineira de Química and INCT Acqua for financial support.

\section{References}

1. Tavares GA, Ferreira JR, de Oliveira CR (2003) Histórico da presença de metais pesados $(\mathrm{Hg}, \mathrm{Cu}, \mathrm{Mn}, \mathrm{Cr}$ e $\mathrm{Ni})$ na lagoa rio das Pedras, Bacia do rio Moji-Guaçu-SP, Brasil. Holos Environment 3: 74-84.

2. Espíndola EL, Brigante J, Eler M (2003) Preliminary environmental assessment of the land use and occupation of the Mogi-Guaçu river basin.

3. De Godoy MP (1975) Peixes do Brasil, subordem Characoidei, bacia do Rio Mogi Guassu-v 1-4.

4. Scheef G, Sures B, Taraschewski H (2000) Cadmium accumulation in Moniliformis moniliformis (Acanthocephala) from experimentally infected rats. Parasitology research 86: 688-691.

5. Schludermann C, Konecny R, Laimgruber S, Lewis JW, Schiemer F, et al (2003) Fish macroparasites as indicators of heavy metal pollution in river sites in Austria. Parasitology 126: S61-69.

6. Sures B (2001) The use of fish parasites as bioindicators of heavy metals in aquatic ecosystems: a review. Aquatic Ecology 35: 245-255.

7. Sures B, Taraschewski H, Jackwerth E (1994) Lead content of Paratenuisentis ambiguus (Acanthocephala), Anguillicola crassus (Nematodes) and their host Anguilla anguilla. Diseases of aquatic Organisms 19: 105-107.

8. Sures B, Taraschewski H (1995) Cadmium concentrations in two adult acanthocephalans, Pomphorhynchus laevis andacanthocephalus lucii, as compared with their fish hosts and cadmium and lead levels in larvae ofa. Lucii as compared with their crustacean host. Parasitology Research 81: 494-497.

9. Meschiatti AJ, Arcifa MS (2009) A review on the fishfauna of Mogi-Guaçu River basin: a century of studies. Acta Limnologica Brasiliensia 21: 135-159.

10. Lourdes AM, Mimura A, Sousa RA Silva JC (2016) Ultrasound-assisted Extraction of $\mathrm{Cr}, \mathrm{K}, \mathrm{Na}, \mathrm{Pb}$, and $\mathrm{Zn}$ in NPK Fertilizers and Determination by FAAS and FAES. Atomic spectroscopy 37: 120-124.

11. Mimura A, Oliveira MA, Ciminelli VS, Silva JC (2016) Optimization of UltrasoundAssisted Extraction of $\mathrm{Cr}, \mathrm{Cu}, \mathrm{Zn}, \mathrm{Cd}$, and $\mathrm{Pb}$ from Sediment, Followed by FAAS and GFAAS Analysis. Journal of AOAC International 99: 252-259.

12. Silva JC, Garcia EE, Nogueira AR, Nóbrega JA (2001) Determination of dysprosium and europium in sheep faeces by graphite furnace and tungsten coil electrothermal atomic absorption spectrometry. Talanta 55: 847-854.

13. Sures B, Siddall R, Taraschewski H (1999) Parasites as accumulation indicators of heavy metal pollution. Parasitology Today 15: 16-21.

14. Di Giulio RT, Hinton DE (2008) The toxicology of fishes. Crc Press

15. Sures B, Steiner W, Rydlo M, Taraschewski H (1999) Concentrations of 17 elements in the zebra mussel (Dreissena polymorpha), in different tissues of perch (Perca fluviatilis), and in perch intestinal parasites (Acanthocephalus lucii) from the subalpine lake Mondsee, Austria. Environmental Toxicology and Chemistry 18: 2574-2579.

16. Galli P, Crosa G, Ambrogi AO (1998) Heavy metals concentrations in Acanthocephalans parasites compared to their fish host. Chemosphere 37 2983-2988.

17. Nachev M, Zimmermann S, Rigaud T, Sures B (2010) Is metal accumulation in Pomphorhynchus laevis dependent on parasite sex or infrapopulation size? Parasitology 137: 1239.

18. Thielen F, Zimmermann S, Baska F, Taraschewski H, Sures B (2004) The intestinal parasite Pomphorhynchus laevis (Acanthocephala) from barbel as a bioindicator for metal pollution in the Danube River near Budapest, Hungary. Environmental Pollution 129: 421-429.

19. Baird C (2002) Química Ambiental Maria Angeles Lobo Rocio e Luiz Carlos Marques Carea. 2nd edn. Bookman, Porto Alegre, pp: 730-745

20. Hilbig CC, Bombardelli RA, Sanches EA, de Oliveira JD, Baggio DM (2008) Efeito do chumbo sobre a fertilização artificial e incubação de ovos de jundiá cinza (Rhamdia quelen). Acta Scientiarum. Animal Sciences 30: 217-224.

21. Sampaio FG, Boijink CL, Rantin FT (2013) The use of copper sulphate in aquatic ecosystems: factors that affect its toxicity in freshwater fish. Série Documentos 91

22. Azevedo FA, Nascimento ES, Chasin AM (2003) Mercury. In: Azevedo FA Chasin AAM, organizers. Metals: toxicity management. São Paulo: Atheneu 299-352.

23. Ramos RO, Peret AC, Ramos SM, Melo JS (2010) Parâmetros reprodutivos do curimbatá no rio Mogi-Guaçu. Rev. Ceres, Viçosa 57: 520-525.

24. Fellous S, Salvaudon L (2009) How can your parasites become your allies? Trends in parasitology 25: 62-66. 